\title{
On the seismic noise monitoring of wave impacts on a seawall
}

\section{Vincent ALLEGRE ${ }^{1}$, Alain DENIS ${ }^{1}$, Mathilda CUNY 1, Sylvain MATEO ${ }^{\text {, }}$ Fabien NAESSENS ${ }^{1}$, Nadia SENECHAL ${ }^{2}$}

1. Université de Bordeaux, I2M, UMR 5295, 33400 Talence, France. vincent.allegre@u-bordeaux.fr

2. UMR CNRS 5805 EPOC - OASU - Université de Bordeaux, Allée Geoffroy SaintHilaire, CS 50023, 33615 Pessac Cedex, France.

\begin{abstract}
:
We investigate the potential of seismic ambient noise to estimate the mechanical and geotechnical response of a seawall to waves' impacts, especially in the context of a storm. This study is part of a project that focuses on hydro-sedimentary processes and protection infrastructures (HOOPLA, EC2CO-2019). Seismic ambient noise measurements were performed continuously of one cycle of spring tides, i.e., with large tidal coefficient, in December 2018.

Continuous recordings of 3 to 4 hours of passive seismic signals were acquired using a network of 12 single-component vertical and horizontal geophones. The network was completed by 3-components sensor. The seismic events that we recorded were classified in three categories. Most of the events were related to run-up occurring during tide rising, some of the seismic events could be associated with actual wave impacts on the seawall. The classification of the events was based the attributes of the seismic signals (e.g., amplitude and frequency), and the process was helped by using the video-footage that was captured during the experiment. The cross-shaped 12-sensors array helped use to discuss the localization of the seismic events, as well as directivity effects and attenuation within the seawall structure.

This work is promising and should contribute to the understanding of the mechanical response to impacts for numerical modeling.
\end{abstract}

Keywords:

Seismic ambient noise, Protection infrastructures, Coastal erosion

\section{Introduction}

The deployment of a seawall on a beach is one of the hard coastal defense structures, such as seawalls or breakwaters that public authorities can use to prevent submersion and to manage coastal erosion hazards. Hard-defense structures have been a popular choice in the past, especially in areas with a significant anthropogenic impact (MANNO et al., 2016). However, such a choice is not without consequences since that kind of defense can disturb the sedimentary near-shore processes and severely impact coastal erosion (FLETCHER et al., 1997; BALAJI et al., 2017). While most of the studies that revealed 


\section{Thème 3 - Instrumentation, mesures, imagerie et télédétection}

that counter-part relied on the observation of aerial and satellite photographs, only a handful of them aimed to estimate the erosion mechanisms of the in-situ processes occurring in the surf zone and in the shoreline zone (PLANT \& GRIGGS, 1992). Part of the field work was to investigate the potential of seismic ambient noise monitoring to address the mechanical behavior of the structure itself during rising tides, which is what the current paper focuses on.

There are many examples of geophysical imaging of dams and seawalls, in order to monitor water infiltrations (LOPERTE et al., 2016), or to address structure failure such as seepages in dams (CHO \& YEOM, 2007). Previous work on defense structures includes various geophysical methods such as seismic tomography and electric resistivity tomography (IKARD et al., 2014), or electromagnetic methods (ANTOINE et al., 2015). A few examples can be found on the use of ambient noise processed as Horizontal to Vertical Spectral Ratio to investigate amplification factor (i.e., site effects) and address earthquakes vulnerability of some civil engineering infrastructures (KIM \& PARK, 2015). Recently, seismic interferometry, which is based on continuous seismic noise monitoring and that was historically applied in global geophysics (BRENGUIER et al., 2008), also proved to be a very insightful method to near-surface hydrogeological applications (VOISIN et al., 2016).

To the best of our knowledge, no previous studies focused on seismic noise monitoring associated with wave impacts on defense structure. The goal of this preliminary experiment was to try-out the potential of continuous seismic monitoring to record, identify and localize seismic events associated with beach processes such as run-up and/or actual waves impacts. We installed a seismic array on the top of a seawall to monitor seismic noise during a spring tide event in December 2018.

\section{Materials and methods}

Data were collected during two field campaigns, organized in December 2018 and February 2019 as part of the HOOPLA project (EC2CO) that aimed among other goals to monitor the run-up and surf zone processes in presence of energetic waves, significant beach morphological changes and presence of shoreline protection.

\subsection{The field area}

Located on the south-west French Atlantic coast, Biscarrosse beach is one of the field sites monitored by the French National Network for shoreline observations (SNO Dynalit). Biscarrosse site is characterized by a 17-18 m high dune (ALMAR et al., 2009), a fully open sandy beach with an orientation of about $10.5^{\circ}$ from the north, and a doublebarred system. With a mean tidal range close to $3.2 \mathrm{~m}$ and a maximum spring tidal range reaching $5 \mathrm{~m}$, Biscarrosse has previously been described as a meso- to macro-tidal environment. Mostly dominated by the North Atlantic swell, the wave climate at Biscarrosse undergoes a strong seasonality: during winter seasons (November to March) 


\section{XVI'̀mes Journées Nationales Génie Côtier - Génie Civil \\ Le Havre 2020}

the mean significant wave height $\left(\mathrm{H}_{\mathrm{s}}\right)$ is approximately $2 \mathrm{~m}$, and can surpass $10 \mathrm{~m}$ during storm events, while it can be less than $0.5 \mathrm{~m}$ during summer seasons (BIAUSQUE \& SENECHAL, 2019). The northern part of the beach-dune system is protected by sand fences set up by the ONF (National Forests Office in France), while the southern end of the dune foot is fixed by a $100 \mathrm{~m}$ long seawall (figure 1). The effect of those management strategies on the system sediment budget can be assumed as negligible, except around the seawall section (BIAUSQUE \& SENECHAL, 2018).



Figure 1. View of the seawall at Biscarrosse Beach at low tide during spring conditions. One can notice the eroded dune front and the side-effect at the seawall on the shoreline retreat.

\subsection{Data collection}

In the present work, we will focus on data collected along this seawall section. We set-up a seismic array, composed of 12 geophones on the top of the seawall (figure 2). The seismic array was cross-shaped and allowed us to record continuous, 3 to 4 hours long, seismic signals during one rising tidal cycle. The cross-shaped seismic network was composed of six nodes of 1 vertical and 1 horizontal geophones (RTC $4.5 \mathrm{~Hz} 1$ component geophones). An additional 3-components (3-C) autonomous geophone (PASI $4.5 \mathrm{~Hz}$ sensor) was placed in the middle of the array (figure 2). The 3-C sensor was expected to help us discussing the directivity characteristics of the seismic waves. The acquisition was performed using a DAQlink 4 unit (Seismic source co.) in continuous mode. We continuously recorded 5-minutes windows at each node, that we concatenated into longer time-series afterwards. One node (1/2) was located down on the beach, i.e., in front of the seawall, providing us a "reference signal" avoiding any influence from the seawall. The alongshore geophones profile (figure 2) aimed to focus on directivity and heterogeneities along the seawall, while the West-East line was supposed to help with attenuation. Unfortunately, we had some sensitivity issues using the horizontal geophones and only vertical components will be discussed in the following. 


\section{Thème 3 - Instrumentation, mesures, imagerie et télédétection}

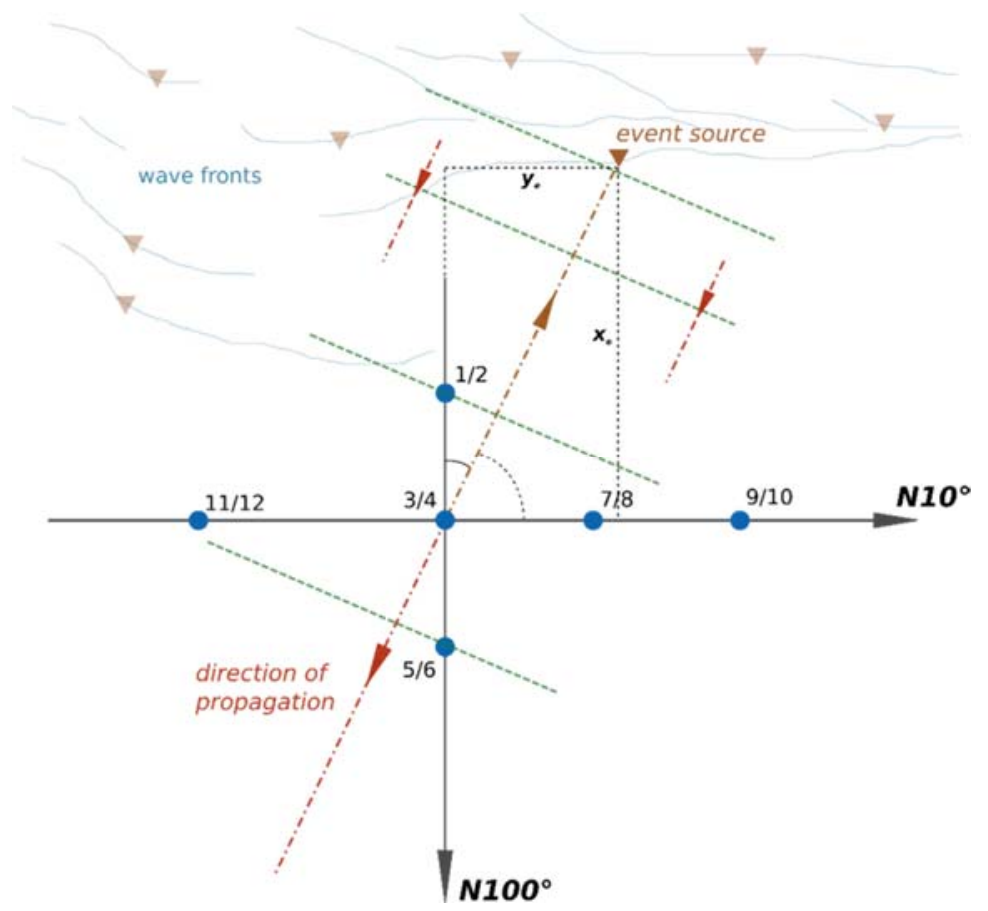

Figure 2. Scheme of the seismic array used to record ambient noise. Twelve geophones were deployed as six nodes (blue dots). The black line oriented alongshore indicates the seawall, so that nodes $11 / 12,3 / 4,7 / 8$ and 9/10 are on the structure. The nodes 1/2 and $5 / 6$ are on the front and on the back of the seawall respectively.

\section{Results and discussion}

\subsection{Environmental conditions}

Results will focus on two specific 4 hours' period centered around high tides on Dec. $18^{\text {th }}$ and Dec. $19^{\text {th }}$. Significant wave height measured in about 54 meters water depth by a wave buoy deployed about 15 miles WNW of the field area (CANDHIS network - Cap Ferret wave Buoy), reached $2.2 \mathrm{~m}$ on the first day (residual waves from a previous storm) and rapidly increased to $5 \mathrm{~m}$ on the second day associated with an increase of the wave period from $11 \mathrm{~s}$ to $14 \mathrm{~s}$ (new storm). Those two days were characterized by neap tide conditions associated with a tidal range of respectively $2 \mathrm{~m}$ and $2.4 \mathrm{~m}$. However, the storm surge allowed the waterline to reach the seawall, due to energetic wave conditions experienced during the whole period of the experiment, Following the classification proposed by SALLENGER (2000), the storm impact scale was 1 until mid-tide with typical "swash" regime (i.e., run-up confined to the foreshore) but rapidly evolved to level 2 , the "collision" regime and in some cases level 3 "over wash" regime were observed. Wave reflection on the seawall has also been observed and are discussed in the following sections. 


\section{XVI èmes Journées Nationales Génie Côtier - Génie Civil \\ Le Havre 2020}

\section{$\underline{3.2 \text { Seismic signals }}$}

The several hours long time-series were built upon dozens of 5-minutes acquisitions, that were continuously saved, so that no gaps occurred. The vertical ground velocity recorded on Dec. $18^{\text {th }}$ by the node $1 / 2$ ranges between $-500 \mu \mathrm{m} / \mathrm{s}$ and $500 \mu \mathrm{m} / \mathrm{s}$ (figure $3 \mathrm{a}$ ). The overall amplitude of the signal increased with time which correlates with the increase of water level as the tide rose. We can see a lot of "peaks", that we will called seismic "events" in the following. Most of them, at least the most energetic ones, occurred during the last 45 minutes to last hour of the rising tide (figure $3 \mathrm{c}$ ). We know that as this time, the tide was high enough so that the waterline reached the base of the seawall and mostly experienced the "collision" regime. Therefore, we argue that these events are related to actual impacts on the seawall, while previous events could be related to other sources, as we discuss in the following. Earthquake seismology commonly uses the peak ground velocity (PGV) to estimate seismic amplitudes, which is the maximum ground velocity (in $\mathrm{m} / \mathrm{s}$ ) recorded for an event. A PGV value around $0.5 \mathrm{~mm} / \mathrm{s}$ (figure $3 \mathrm{a}$ ) yields to a peak ground acceleration (PGA) to be around $30 \mathrm{~mm} / \mathrm{s}^{2}$, which corresponds to $0.003 \mathrm{~g}$ or $0.3 \% \mathrm{~g}$, where $g$ is gravity (with $g=9.81 \mathrm{~m} / \mathrm{s}^{2}$ ). For one to have a sense of this value, the PGA created by the $M_{w}=4.9$ Montendre earthquake (Charentes-Maritimes, France), that occurred on March $20^{\text {th }} 2019$, was around 5-6\% $g$ at the epicenter and around $1 \% \mathrm{~g}$ in the Bordeaux area, approximately $50 \mathrm{~km}$ from the epicenter.

The frequency content of the time-series was computed as a spectrogram (figures $3 b-3 d$ ), and ranges between 0 and $125 \mathrm{~Hz}$, which is half the sampling frequency $(250 \mathrm{~Hz})$ according to the Nyquist-Shannon theorem (SHANNON, 1949). The spectrogram shows a low frequency, base-line component in the signal ranging from $\sim 1 \mathrm{~Hz}$ up to $\sim 5 \mathrm{~Hz}$, that may correspond to the wind, which is known to increase the seismic noise amplitude (MUCCIARELLI et al., 2005). We notice that some of the energy seems to shift from 80 $\mathrm{Hz}$ to around $60 \mathrm{~Hz}$ as the tide rose, between 10:15 GMT and 12:00 GMT (figure 3b), suggesting that dispersion occurred. That change in the spectral content is time-correlated with the increasing height of the water column, especially when the water reached the seawall, involving that the waves propagated to that specific sensor (node 1/2) through fully saturated sand. We observe that until 11:45 GMT, the seismic time-series does not show major events, and the amplitude reached a maximum around $10^{-4} \mathrm{~m} / \mathrm{s}$. That part of the recordings was most likely controlled by the "swash" regime, occurring tens of meters from the seawall. Obviously, the seawall-to-shoreline distance continuously decreased over the course of the experiment. Towards the end of the recordings, we identify larger amplitude arrivals (figure $3 \mathrm{~d}$ ) that we associate with actual impacts. 


\section{Thème 3 - Instrumentation, mesures, imagerie et télédétection}
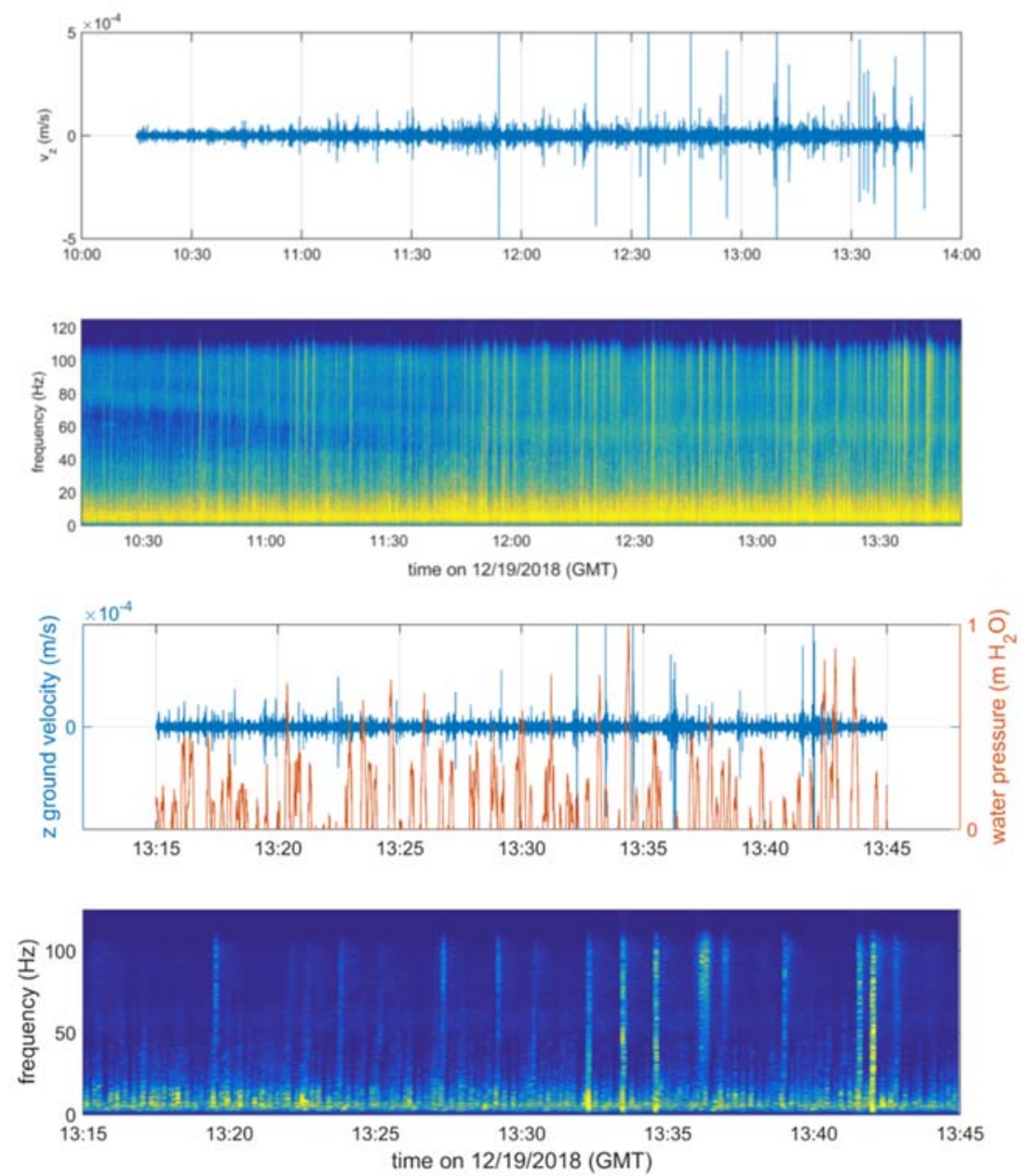

Figure 3. Time-series of the vertical seismic velocity recorded on the seawall (a), and corresponding spectrogram (b). Last 30 minutes of the time-series (c), and corresponding spectrogram $(d)$. The orange curve represents the water pressure measured a few hundred meters North of the actual experiment.

\subsection{Classification of the events}

In order to properly separate "swash" regime from "collision" regime, we conducted a systematic comparison between the signals and the video-footage that were recorded during the experiment (figure 4). Although the angle was not ideal, we managed to synchronize the entire seismic time-series to the video, and then classified the events in three categories: class \#1. no impact on the seawall, i.e., "swash" regime; class \#2. possible impact and "collision" regime; and class \#3. confirmed impact, with the observation of a reflected wave and in some rare cases "over wash" events. The footage led to the count of 51,72 , and 22 class $\# 1, \# 2$ and $\# 3$ events respectively. This classification allowed us to isolate the events from the rest of the signal, in order to infer some statistics on attenuation and directivity (see section 3.5). The figures $3 \mathrm{c}-\mathrm{d}$ compares seismic noise recordings to the water pressure measured across-shore. Although, the 


\section{XVİ̀mes Journées Nationales Génie Côtier - Génie Civil \\ Le Havre 2020}

correlation is far from perfect, it seems that water pressure peaks are observed at similar time as "seismic bursts" that we can define as small series of run-up events and/or impacts. However, we observe phase shifts that seem to vary in length depending on the events. Moreover, the seismic signal appears more energetic at higher tide, which may seem obvious since the source is closer to the sensors. Additionally, we observe a broader range in the frequency content as soon as the water covers up the beach (figure $2 b$, after 11:45 GMT). Beforehand, the water level does not seem to influence the seismic signal that much. We believe that the correct water pressure profile, as well as the wave velocity helps us with energy calibration for a wave impact

on the seawall that could then be converted to seismic energy. Future work will investigate such a calibration that should help numerical modeling developments.

\subsection{Frequency content of the arrivals}

Using the 3-C sensor time-series and associated spectrum (figure 5), we were able to identify three frequency domains. The "low"-frequency part below 5-6 Hz (black on figure 4) is most likely related to wind (MUCCIARELLI et al., 2005). The "middle"frequency range occurred with a clear peak in the spectral domain around $10 \mathrm{~Hz}$ (orange on figure 4). The corresponding time-series shows that $10 \mathrm{~Hz}$ component is quite consistent across the entire recordings, i.e., it is mostly related to events created by runup.

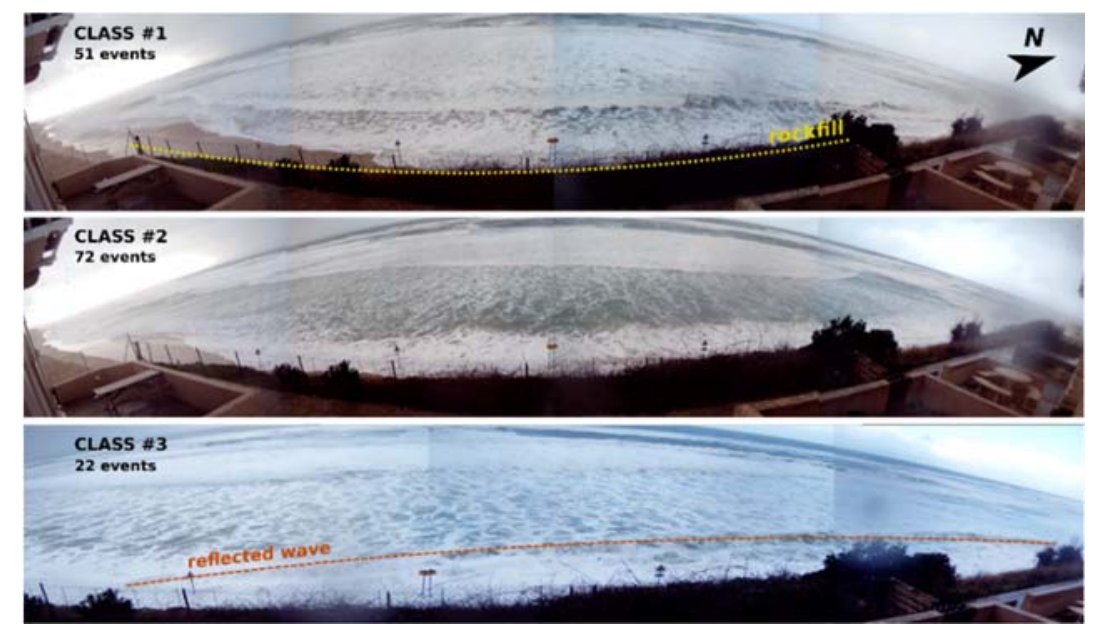

Figure 4. Screenshots of the video-footage of the experiment. The top panel, middle panel, and bottom panel shows the class \#1, \#2 and \#3 events respectively.

Finally, it seems that larger amplitude and more impulsive events are composed by the superposition of that $10 \mathrm{~Hz}$ component and an "high"-frequency content of the spectrum which appears with a clear peak around $22 \mathrm{~Hz}$. We believe that the higher-frequency range is associated with proper impacts on the seawall. The spectrogram presented on figure 3 confirms that higher frequency signals were observed mostly towards the end of 


\section{Thème 3 - Instrumentation, mesures, imagerie et télédétection}

the time-series. Additionally, the high-frequency domain mostly appears on the WestEast axis. However, a systematic discrimination is still difficult since one wave impact may produce a different frequency content than another impact. We computed a polar diagram representing the spectral content as a function of azimuth (figure 5). The lowfrequency maximum is retrieved towards west which is consistent with the wind. The mid-frequency, i.e., run-up related events, appears to be oriented towards west to northwest, with a maximum amplitude at $\mathrm{N} 297^{\circ}$. Finally, it seems that the energy at higherfrequency is gathered around two clusters around $\mathrm{N} 330^{\circ}$ (at $20^{\circ}$ on figure 5), and from south-to-west, that might indicate the main location of wave impacts on the seawall. Consequently, we believe that further measurements using a network of 3-C sensors, for a longer period of time, will lead to a much finer interpretation on localization of wave impacts events.



Figure 5. (a) Time-series and corresponding amplitude spectrum of the 3-C sensor for vertical axis (top), alongshore (middle) and across-shore axis (bottom). The black, orange and blue curves show pass-filtered signal below $6 \mathrm{~Hz}$, below $16 \mathrm{~Hz}$, and above

$16 \mathrm{~Hz}$ respectively. The time axis is relative to the start of the experiment; zero corresponding to 13:15 GMT. (b) Polar diagram representing the azimuthal amplitude spectrum of the 3-C sensor (figure 1). The distance along meridian indicates frequency

$(\mathrm{Hz})$. The angular scale is relative, as the $0^{\circ}$ angle on the $\mathrm{x}$-axis means alongshore.

\section{Conclusions and perspectives}

We successfully measured seismic ambient noise on the top of a seawall during one cycle of a rising tide. A few hours long time-series allowed us to identify and classify three types of events, which we used to discriminate the run-up related events and from the events created by proper wave impacts on the seawall. Using a single 3 components seismometer, we were able to link the frequency content of the recordings to azimuth, that confirms a seismic network can be used to monitor and localize the events on the seawall. In terms of amplitude, the most energetic events we identified, corresponding to direct wave impact on the seawall produced a PGA around $0.3 \% \mathrm{~g}$ which seems to be reasonable. Future developments should include the use of denser network of 3components seismometers to provide finer interpretation in terms of amplitude and 


\section{XVIèmes Journées Nationales Génie Côtier - Génie Civil \\ Le Havre 2020}

attenuation, as well as ambient noise interferometry. Further work will also have to investigate similar structure in comparable weather conditions, i.e., spring tides.

\section{References}

ALMAR R., CASTELLE B., RUESSINK B.G., SENECHAL N., BONNETON P., MARIEU V. (2009). High-frequency video observation of two nearby double-barred beaches under high-energy wave forcing, J. Coastal Research, SI56, pp 1706-1710.

ANTOINE R., FAUCHARD C., FARGIER Y., DURAND E. (2015). Detection of leakage areas in an earth embankment from GPR measurements and permeability logging, International journal of geophysics, 9. https://doi.org/10.1155/2015/610172

BALAJI R., SATHISH KUMAR S., MISRA A. (2017). Understanding the effects of seawall construction using a combination of analytical modeling and remote sensing techniques: case study of Fansa, Gujarat, India. Int. J. Ocean Climate Syst., Vol. 8(3), pp 153-160. https://doi.org/10.1177/1759313117712180

BIAUSQUE M., SENECHAL N., (2018). Storms impacts on a sandy beach including seasonal recovery: longshore variability and management influences. Revue Paralia, Vol. 11, n02.1-n02.16. https://doi.org/10.5150/revue-paralia.2018.n02

BIAUSQUE M., SENECHAL N., (2019). Seasonal morphological response of an open sandy beach to winter wave conditions: The example of Biscarrosse beach, SW France. Geomorphology, Vol. 332, pp 157-169. https://doi.org/10.1016/j.geomorph.2019.02.009 BRENGUIER F., SHAPIRO N. M., CAMPILLO M., FERRAZZINI V., DUPUTEL Z., COUTANT O., NERCESSIAN A. (2008). Towards forecasting volcanic eruptions using seismic noise, Nature Geosciences, Vol. 1, pp 126-130. https://doi.org/10.1038/ngeo104 CHO I.-K., YEOM J.-Y. (2007). Crossline resistivity tomography for the delineation of anomalous seepage pathways in an embankment dam, Geophysics, 72(2), G31-G38. https://doi.org/10.1190/1.2435200

FLETCHER C. H., MULLANE R. A., RICHMOND B. M. (1997). Beach loss along armored shorelines on Oahu, Hawaiian Islands, Journal of coastal Research, Vol. 13(1), pp 209-215.

IKARD S. J., RITTGERS J., REVIL A., MOONEY M. A. (2014). Geophysical investigation of seepage beneath an earthen dam, Groundwater, Vol. 53(2), pp 238-250. https://doi.org/10.1111/gwat.12185

KIM K. Y., PARK Y. G. (2015). Micro tremor response of the Cheong-cheon dam in Korea, Exploration Geophysics, Vol. 47(2), pp 115-122. https://doi.org/10.1071/EG15019 LOPERTE A., SOLDOVIERI F., PALOMBO A., SANTINI F., LAPENNA V. (2016). An integrated geophysical approach for water infiltration detection and characterization at Monte Cotugno seawall dam (southern Italy), Engineering Geology, Vol. 211, pp 162-170. https://doi.org/10.1016/j.enggeo.2016.07.005 
Thème 3 - Instrumentation, mesures, imagerie et télédétection

MUCCIARELli M., GALliPOLI M. R., DI GIACOMO D., DI NOTA F., NINO E. (2005). The influence of wind on measurements of seismic noise, Geophysical Journal International, Vol. 161, pp 303-308. https://doi.org10.1111/j.1365-246X.2004.02561.x

MANNO G., ANFUSO G., MESSINA E., WILLIAMS A. T., SUFFO M., LIGUORI V. (2016). Decadal evolution of coastal armouring along the Mediterranean Andalusia littoral (South of Spain), Ocean \& Coastal Management, Vol. 124, pp 84-99. https://doi.org/10.1016/j.ocecoaman.2016.02.007

PLANT N. G., GRIGGS G. B. (1992). Interactions between nearshore processes and beach morphology near a seawall, Journal of Coastal Research, Vol. 8, pp 183-200, https://www.jstor.org/stable/4297962

SALLENGER A.H. (2000). Storm impact scale for barrier islands. Journal of Coastal Research, Vol. 16(3), pp 890-895. https://www.jstor.org/stable/4300099

SHANNON C. E. (1949). Communication in the presence of noise, Proceedings of the institute of radio engineers, Vol. 37 (1), pp 10-21.

VOISIN C., GARAMBOIS S., MUSSEY C., BROSSIER R. (2016). Seismic noise monitoring of the water table in a deep-seated, slow-moving landslide, Interpretation, Vol. 4(3), SJ67-SJ76. https://doi.org/10.1190/INT-2016-0010.1 